\title{
Antibacterial Activities of Calpurnia aurea against Selected Animal Pathogenic Bacterial Strains
}

\author{
Getachew Mulatu (D) \\ Department Veterinary Laboratory Technology, College of Agriculture and Veterinary Sciences, Ambo University, P.O. Box 19, \\ Ambo, Ethiopia \\ Correspondence should be addressed to Getachew Mulatu; getachew.mulatu@ambou.edu.et
}

Received 19 June 2020; Revised 9 September 2020; Accepted 22 September 2020; Published 17 November 2020

Academic Editor: Ergin Murat Altuner

Copyright (C) 2020 Getachew Mulatu. This is an open access article distributed under the Creative Commons Attribution License, which permits unrestricted use, distribution, and reproduction in any medium, provided the original work is properly cited.

The study aimed to determine the phytochemicals and to assess the antibacterial activities of crude extracts of different parts of Calpurnia aurea against Staphylococcus aureus, Streptococcus pyogenes, Listeria monocytogenes, Escherichia coli O157 H:7, Salmonella typhi, and Campylobacter jejuni. The fresh and healthy leaves, barks, stems, and roots of the plant parts were collected, herbarium, dried, and grounded, and bioactive compounds were extracted by ethanol (99\%) and water. Mass of crude extracts was determined by using the Whatman No. 1 filter paper and rotary evaporator. Major secondary metabolites were also screened using phytochemical screening tests. Antibacterial activities (inhibition zones, $\mathrm{mm}$ ) and minimum inhibition concentrations (MIC) were evaluated using agar-well diffused methods and agar dilution methods, respectively. The antibiotics ciprofloxacin, amoxicillin, penicillin, and tetracycline were used as positive controls at concentrations of $0.1 \mathrm{mg} / \mathrm{ml}$ and $0.2 \mathrm{mg} / \mathrm{ml}$, while distilled water was used as the negative control. All the crude extracts were tested triplet $(3 \mathrm{x})$ for antibacterial activities against selected bacterial strains with two different concentrations 25 and $50 \mathrm{mg} / \mathrm{ml}$ and analyzed to compare the mean \pm standard deviation between triplets. The results revealed that ethanol extracts showed high crude mass extracts, antibacterial activities, and major secondary metabolites such as alkaloids, tennis, flavonoids, saponins, steroids, and phlobatannins compared with aqueous extracts. Among antibiotics used, penicillin showed resistance to S. aureus and E. coli O157 H:7. C. jejuni was found to be the most susceptible bacterium to ethanol extracts' leaves, barks, and stems with MIC $3.125 \mathrm{mg} / \mathrm{ml}$, whereas $S$. aureus was the least susceptible to all crude extracts. The study provided the traditional and scientific basis of Calpurnia aurea used against some bacterial diseases.

\section{Background}

In Ethiopia, people have been using ethnomedicinal plants traditionally to treat both human and animal diseases. It is documented that approximately $80 \%$ of the Ethiopian population relies on traditional medicine to cure ailments [1] since plants are rich in a wide diversity of secondary metabolites that have been found to exhibit antimicrobial, antioxidant, anti-infectious, and antitumor activities [2]. Also, plants are the most naturally effective and cheapest sources of drugs [3]. Especially, ethnoveterinary medicine is a holistic interdisciplinary study of the local knowledge, sociocultural structures, and environment associated with animal healthcare and husbandry to use medicinal plants [4]. Natural herbivore animals consumed or grazed herbs which might have tremendous antimicrobial activities to improve their life quality and maintain their health [5]. Such traditional medicine is still being used in rural and urban areas, but it is more widely practiced in rural areas where there is limited modern health service. However, little work has been done to promote traditional medicine which can be commercially available for veterinary practitioners [6].

Among ethnomedicinal plants, Calpurnia aurea (local name chekka by Afan Oromo) is a yellow-flowered shrub that is widely distributed throughout tropical Africa and has several ethnomedical uses in Ethiopia [7]. Calpurnia aurea is used for the treatment of amoebic dysentery and diarrhea, killing head lice, tapeworm and ticks, stomach-ache, bowel, syphilis, leishmaniasis, trachoma, bladder disorders, tinea capitis, wound, scabies, and elephantiasis different swellings 
in humans and animals [8]. According to some reports, this plant has secondary metabolic compounds such as saponins, steroids, alkaloids, tannins, flavonoids, terpenoids, and phlorotannins which were extracted from leaves, barks, stems, and roots of the plant by different extraction fluids such as ethanol, methane, acetone, and water [7, 9-12]. The secondary metabolic compounds of this plant have antimicrobial activities against pathogenic bacterial strains such as Escherichia coli, Staphylococcus aureus, Salmonella spp., Lactobacillus spp., Streptococcus spp., Bacillus subtilis, Klebsiella pneumonia, Pseudomonas aeruginosa, Shigella sonnie, Shigella dysenteriae, Vibrio cholerae microbacterium, and others reported by [9, 13-15].

Salmonella is a rod-shaped Gram-negative bacterium belonging to the family Enterobacteriaceae and is the causative agent of salmonellosis, which is characterized by two major syndromes: systemic septicemia and enteritis. Also, it can cause diarrhea, abortion, arthritis, respiratory diseases, necrosis of extremities, and meningitis. S. typhi and S. paratyphi produce typhoid in people, S. gallinarum in poultry, S. abortusovis in sheep, S. choleraesuis in pigs, S. dublin in cattle, etc. [16-18].

Campylobacter spp. are spiral, microaerobic, and Gramnegative bacteria that cause gastroenteritis in people and animals, e.g., C. jejuni subsp. jejuni (enteritis and abortion), C. coli, C. mucosalis (porcine enteritis), C. hyointestinalis subsp. hyointestinalis (porcine and bovine enteritis), C. sputorum (abortions in sheep), and C. fetus subsp. fetus (isolated from intestinal tracts of sheep and cattle, sporadic abortions) $[17,19,20]$.

Listeriosis is a sporadic bacterial infection that affects a wide range of animals, people, and birds [21]. Listeria monocytogenes is a small, motile, Gram-positive, nonsporeforming, extremely resistant, diphtheroid coccobacillus that grows under a wide temperature range of $4^{\circ}-44^{\circ} \mathrm{C}$. The uterus of all domestic animals (ruminants) is highly susceptible to infection with L. monocytogenes at all stages of pregnancy, and it causes placentitis, fetal infection and death, abortion, stillbirths, neonatal deaths, metritis, and possibly viable carriers [19].

Escherichia coli is a Gram-negative, rod-shaped bacterium normally found in the intestine of poultry and most other animals. Colibacillosis occurs as acute fatal septicemia or subacute pericarditis, air vasculitis, salpingitis, and peritonitis. It is a common disease of economic importance in poultry and animals worldwide. However, no single E. coli serogroup used as a bacterium can provide full protection against all of the serogroups that cause infections. Virulence factors include possession of large virulence plasmids and the ability to resist phagocytosis and serum killing, acquire iron in low iron conditions, and adhere to host structures $[19,22]$.

Staphylococcus aureus is most commonly isolated from staphylococcosis cases, which is a Gram-positive, catalase-positive, and coccoid bacterium that appears in grape-like clusters on stained smears, but species such as S. hyicus have also been reported as the causative agent of osteomyelitis in Turkey poultry. Economic losses may result from decreased weight gain, decreased egg production, lameness, mortality, and condemnation at slaughter $[19,23,24]$.

Streptococci are nonmotile, Gram-positive, and catalasenegative coccoid bacteria that occur singly, in pairs, or as short chains when observed on stained smears. Streptococcus species commonly associated with disease in avian species include S. pyogenes, S. zooepidemicus (S. gallinarum), S. bovis, S. dysgalactiae, S. gallinaceus, and S. mutans. Streptococci have been associated with acute septicemia, acute mortality with lameness, inappetence, diarrhea, joint infections, cellulitis, osteomyelitis, and endocarditis [22, 25].

Calpurnia aurea is scattered all over the parts of the country, and a sizable number of it has been used for the general treatment of diseased animals. However, there is no scientific basis for the therapeutic actions of traditional Calpurnia aurea medicines which might serve as the source for the development of more effective drugs. So, the objective of the current study was to evaluate the antimicrobial activities and to determine phytochemicals of crude extracts of Calpurnia aurea against a selected isolate of animal pathogenic bacterial strains.

\section{Materials and Methods}

2.1. Description of the Study Area. The study was conducted in selected kebeles of Guder town, West Shewa Zone of Oromia Regional State, which was located at $126 \mathrm{~km}$ west of Addis Ababa. The climatic condition of the area was $23 \%$ highland, $60 \%$ midaltitude, and $17 \%$ low land. It has annual rainfall and temperature ranging from 800 to $1100 \mathrm{~mm}$ and 16 to $22 \mathrm{C}$, respectively. The rainfall was bimodal with the short rainy season from February to May and the long rainy season from June to September. The area was found at a longitude of $37046^{\prime}$ to 38 east and latitude of $8059^{\prime}$ to $9020^{\prime}$ north, and the altitude range is from 1600 to 3192 meters above the sea. The mixed type of agricultural activities was the practice in the area. The total livestock population was cattle 145,410 , shoats 56,349 , equine 44,845 , and poultry 60,845 [26], but livestock productivity was poor due to prevalent diseases, malnutrition, poor genetic makeup, and management constraints.

2.2. Collection of the Plant Material. Healthy and fully matured leaves, barks, stems, and roots of Calpurnia aurea used in this study were collected in plastic bags appropriately labeled from Guder town between September and October 2018. The collected plant parts were confirmed by plant taxonomists and authenticated (herbarium) in the Plant Science Laboratory of Ambo University Guder campus.

2.3. Preparation of Crude Extracts. The collected plant parts were separately washed using tap water followed by sterilized distilled water and cut into smaller sizes of about $1-2 \mathrm{~cm}$ long. The washed plant parts were then shade-dried at room temperature for 15 days, pounded using an electric grinder into a fine powder, and finally kept in a refrigerator $\left(4^{\circ} \mathrm{C}\right)$ until use. 
2.3.1. Preparation of Aqueous Extracts. Crude plant part extracts were obtained by separately suspending $200 \mathrm{~g}$ of each plant material in $1000 \mathrm{ml}$ distilled water to give $20 \%(\mathrm{w} /$ v) in a $2000 \mathrm{ml}$ conical flask. The resulting leaf, bark, stem, and root powder suspension was then shaken at $121 \mathrm{rpm}$ for $24 \mathrm{hrs}$ using a shaker to produce the required infusion. After filtering the infusion using a double-layer cheesecloth and Whatman No. 1 filter paper, the filtrates were centrifuged for $15 \mathrm{~min}$ at $6000 \mathrm{rpm}$. The supernatants of the extracts were then preserved in airtight bottles until further use in the refrigerator $\left(4^{\circ} \mathrm{C}\right)$ [27].

2.3.2. Preparation of Ethanol Extracts. Two hundred grams of air-dried powdered plant materials were placed in $1000 \mathrm{ml}$ of ethanol kept in a conical flask and were shaken in a rotary shaker at $121 \mathrm{rpm}$ for $24 \mathrm{hrs}$. The suspension was filtered with a double-layer muslin cloth and Whatman No. 1 filter paper. The resulting filtrate was concentrated under reduced pressure in a rotary evaporator at 30 to $40^{\circ} \mathrm{C}$ for $30 \mathrm{~min}$. The gummy residue was further dried in a water bath until the solvent was removed. After solvent evaporated, the remaining crude extracts were diluted with $10 \mathrm{ml}$ sterile distilled water and kept in an airtight bottle in the refrigerator until use $[28,29]$.

\subsection{Determination of Yields of Crude Extracts and Major} Secondary Metabolites. Two hundred grams of powdered plant materials were used to obtain crude extracts from each plant part. The percentage yield for each plant part was the amount of crude extract recovered in mass compared with the initial amount of powdered plant materials used. It was presented in percentage (\%) and was determined for each extraction solvent used.

One gram of each powdered sample was separately added into $20 \mathrm{ml}$ of distilled water in test tubes. Then, the mixtures were boiled in a water bath for $7 \mathrm{~min}$ and were filtered while hot using the filter paper into Erlenmeyer flasks. After cooling, $1 \mathrm{ml}$ of the filtrate was diluted to $5 \mathrm{ml}$ solution using distilled water, and then a few drops (2-3) of $10 \%$ ferric chloride were added to it. Formation of bluishblack or brownish-green precipitate indicated the presence of tannins [30].

Solidified extract $(0.5 \mathrm{gm})$ was taken in separate test tubes and mixed with $20 \mathrm{ml}$ of distilled water. The mixtures were boiled in a water bath for $10 \mathrm{~min}$. After cooling, the mixture was separately filtered through a Whatman No. 1 filter paper. Thereafter, $2 \mathrm{ml}$ of $1 \%$ aqueous hydrochloric acid was added to each mixture and shaken to develop red precipitate that indicates the presence of phlorotannins [31].

Two milliliters of chloroform and 10 drops of acetic acid were mixed in a test tube. Then, $0.5 \mathrm{ml}$ of concentrated ethanolic extract was added to the test tube and mixed with the solvent. Next, $1.5 \mathrm{ml}$ of concentrated sulfuric acid was added from the side of the test tube. The change of red color through blue to green indicated the presence of steroids (Liebermann-Burchard test) [32].

Five milliliters of each concentrated ethanolic extract was mixed with $2 \mathrm{ml}$ of chloroform in separate test tubes, and then $2 \mathrm{ml}$ of concentrated sulfuric acid was added carefully and shaken gently to form a layer. Reddish-brown coloration of the interphase confirmed positive results for the presence of terpenoids (Salkowski test) [33].

One gram of each powdered sample was taken in separate test tubes and mixed with $10 \mathrm{ml}$ of distilled water. Then, the mixtures were boiled in a water bath for $10 \mathrm{~min}$ and were filtered while hot into a $50 \mathrm{ml}$ Erlenmeyer flask. The formation which above $1 \mathrm{~cm}$ of foam or froth confirmed the presence of saponins in the filtrate [30].

Two milliliters of each of the concentrated ethanolic extract was added to test tubes. Then, 4 drops of $10 \% \mathrm{NaOH}$ solution were added and heated in a water bath for $10 \mathrm{~min}$. The intensity of yellow color which became colorless on the addition of 10 drops of $1 \%$ hydrochloric acid showed the presence of flavonoids [34].

$1.5 \mathrm{ml}$ of $1 \% \mathrm{HCl}$ was added to $4.5 \mathrm{ml}$ of each concentrated ethanolic extract in different test tubes. Each mixture was heated and shaken for $2 \mathrm{~min}$ in a water bath. It was then cooled and filtered. The resulting filtrate was tested with Dragendorff's reagent for the presence of alkaloids as described by Adachukwu et al. [34]. $1 \mathrm{ml}$ of the filtrate was added to $0.4 \mathrm{ml}$ of Dragendorff's reagent. The formation of cream yellow precipitate indicated the presence of alkaloids.

2.5. Isolated Animal Pathogenic Bacterial Strains. Three strains of Gram-positive bacteria that infect animals, namely, Staphylococcus aureus, Streptococcus pyogenes, and Listeria monocytogenes, and three strains of Gram-negative pathogenic bacteria, Escherichia coli O157 H:7, Salmonella typhi, and Campylobacter jejuni, were obtained from Ethiopian Public Health Institute (EPHI) in icebox and transport media.

All bacterial cultures were first grown on $5 \%$ sheep red blood agar plates at $37^{\circ} \mathrm{C}$ for $18-24 \mathrm{hrs}$ before inoculation onto the nutrient agar. Four up to five colonies of bacteria were selected and transferred with a sterile inoculating loop to a liquid medium and incubated until adequate growth equivalent to McFarland 0.5 turbidity units $\left(1.5 \times 10^{8} \mathrm{CFU} /\right.$ $\mathrm{ml}$ ) standard was obtained. The inocula of the respective bacteria were streaked onto Mueller-Hinton agar (MHA) plates using a sterile swab in such a way as to ensure thorough coverage of the plates, and a uniform thick lawn of growth was obtained following incubation. The inoculated plates were left at room temperature for 3-5 min to allow for any surface moisture to be absorbed before applying the extract. Wells of $6 \mathrm{~mm}$ in diameter were formed onto MHA plates using a sterile cork borer. The wells were filled with the test agents ( $50 \mu \mathrm{l}$ each), and the plates were then allowed to stay for 1-2 hrs at room temperature for proper diffusion. Finally, the plates were incubated at $37^{\circ} \mathrm{C}$ for $18-24 \mathrm{hrs}$, and the resulting diameters of zones of inhibition were measured using a sliding caliper [29].

2.6. Evaluation of the Crude Extracts. The six test pathogens were exposed to aqueous and ethanol extracts of different plant parts (leaves, barks, stems, and roots) by adaptation of the agar-well diffusion method. The growth media were 
prepared following standard procedures. After complete solidification of the media, separate cultures of each species of bacteria were spread aseptically onto each plate. Immediately following this procedure, small wells (each with $6 \mathrm{~mm}$ diameter) on each inoculated plate were prepared aseptically using a sterile cork borer, and extracts of varying concentrations $(25$ and $50 \mathrm{mg} / \mathrm{ml}$ ) were added into the wells. Plates were incubated at $37^{\circ} \mathrm{C}$ for 24 hours [35]. Overall, cultured bacteria with zones of inhibition equal to or greater than $7 \mathrm{~mm}$ were considered susceptible to the tested extract [36].

Ciprofloxacin, amoxicillin, penicillin, and tetracycline were used as positive controls at concentrations of $0.1 \mathrm{mg} / \mathrm{ml}$ and $0.2 \mathrm{mg} / \mathrm{ml}$, with equal amounts as those of the extracts $(50 \mu \mathrm{l})$, and sterile distilled water $(50 \mu \mathrm{l})$ was used as a negative control. All plates were with three replicates. Sizes of colony diameter were measured after 24 hrs of growth at $37^{\circ} \mathrm{C}[17]$.

2.7. Determination of Minimum Inhibitory Concentration $(M I C)$. The ethanol and aqueous extracts of the different plant parts that showed significant antimicrobial activity in the previous test were selected for the determination of MIC. The minimum inhibitory concentration of the crude extracts of the leaves, the barks, the stems, and the roots of Calpurnia aurea was determined by the agar dilution method. The growth media were first prepared in the usual fashion and sterilized by autoclaving. The sterilized media were allowed to cool to $50^{\circ} \mathrm{C}$, and $18 \mathrm{ml}$ of the molten agar was added to test tubes which contain $2 \mathrm{ml}$ of different concentrations of the crude extract and the control. The concentrations of the extracts used in this test ranged from 1.25 to $6.25 \mathrm{ml}$. The plates were dried at room temperature. The suspensions of the respective pathogens having density adjusted to McFarland 0.5 turbidity units $\left(1.5 \times 10^{8} \mathrm{CFU} / \mathrm{ml}\right)$ were inoculated onto the series of agar plates using a standard loop. Three loops of the suspension were transferred into each plate and incubated at $37^{\circ} \mathrm{C}$ for $24 \mathrm{hrs}$. The lowest concentration which inhibited the growth of the respective organisms was taken as the MIC $[16,17]$.

2.8. Data Management and Analysis. All the experiments were carried out in quadrant. Zones of inhibition were analyzed using Statistical Package for Social Sciences, version 16.0 (SPSS, Chicago, IL, USA). Other data were subjected to $T$-test for comparison, while those recorded from disc diffusion tests were analyzed using one-way analysis of variance (ANOVA) with multiple comparison tests to compare the mean \pm standard deviation parameter within and between groups which were considered statistically significant at $p<0.05$.

\section{Results}

3.1. Yields of Crude Extracts. The crude extracts used in this experiment were obtained from the extraction of $200 \mathrm{~g}$ powders of $C$. aurea parts using ethanol and water as extracting solvents. As indicated in Table 1, the number of extracts ranged from $4.2 \%$ to $9.1 \%$. Ethanol extract of the leaves gave the maximum yield (9.1\%) followed by the ethanol extract of the barks $(8.35 \%)$. The lowest yield was obtained from the aqueous extract of the roots (4.2\%).

\subsection{Screened Phytochemicals from Crude Extracts.} Phytochemical (secondary metabolic chemicals) screening of the ethanol extract of the $C$. aurea leaf revealed the presence of terpenoids, alkaloids, tannins, flavonoids, and saponins. C. aurea bark also had alkaloids, saponins, flavonoids, and steroids. The phytochemicals of the stem and root of $C$. aurea were less compared to the leaf and bark by ethanol extracts. Overall, phytochemical crude extracts by aquatic extracts were very low compared to ethanol extracts as shown in Table 2.

3.3. Antimicrobial Activities of Crude Extracts: Agar-Well Diffusion Method. In this study, the antimicrobial activities of the ethanol and aqueous crude extracts of the leaves, barks, stems, and, roots of $C$. aurea were evaluated using the agar-well diffusion method. A total of 8 crude extracts (ethanol and aqueous) were prepared and screened for antimicrobial activities against the test pathogens. The antimicrobial activities of different extracts of $C$. aurea against the six pathogenic bacteria (S. aureus, S. pyogenes, L. monocytogenes, E. coli O157 H:7, S. typhi, and C. jejuni) are presented in Tables 3-6. The antibacterial activities of plant parts extracted by ethanol $50 \mathrm{ml} / \mathrm{mg}$ against all tested isolates were not significantly different from one another $(p>0.05)$. Standard antibiotics (ciprofloxacin, amoxicillin, penicillin, and tetracycline) were used as positive controls and caused significantly higher zone of inhibition against all tested clinical isolates by both extracts $(p<0.05)$ except penicillin against E. coli O157 H:7 and S. aureus. Sterile distilled water which was used as a negative control had no antibacterial activity against all tested isolates (Tables 3-6).

The ethanol and aqueous crude extracts of the leaf at concentrations of 25 and $50 \mathrm{mg} / \mathrm{ml}$ were evaluated for in vitro antibacterial activities against the test pathogens. The zones of inhibition of crude extracts were 1.60-6.90 $\mathrm{mm}$ and 9.63-19.67 mm for aqueous and ethanol extracts, respectively. Ethanol extracts from leaves have a large inhibition zone, especially on L. monocytogenes, as shown in Table 3.

The antibacterial activities of the stem crude extracts were tested on selected pathogenic bacteria which imply that the ethanol extract showed significant growth inhibition against tested bacterial species. As indicated in Table 4, the zones of inhibition of the ethanol and aqueous stem extracts were in the range of $6.33-16.77 \mathrm{~mm}$ and $1.13-7.80 \mathrm{~mm}$, respectively.

Similarly, the bark extracts were also tested for their antibacterial properties against the test pathogens. As indicated in Table 5, the diameters of the zones of inhibition ranged from 0.97 to $5.23 \mathrm{~mm}$ for aqueous bark extracts and $8.07-13.5 \mathrm{~mm}$ for ethanol bark extracts.

The results of the in vitro assays of antibacterial activities of the root extracts on the test pathogens are shown in Table 6. The ethanol extracts of the roots had inhibitory 
TABLE 1: The percentage of yields of crude extracts.

\begin{tabular}{lccc}
\hline Plant parts & Extraction solvents & Crude mass $(\mathrm{g})$ & Percentage of crude yields \\
\hline Leaves & Ethanol & 18.2 & 9.1 \\
& Water & 13.6 & 6.8 \\
Barks & Ethanol & 16.7 & 8.35 \\
& Water & 12.0 & 6 \\
Stems & Ethanol & 15.3 & 7.65 \\
& Water & 10.1 & 5.05 \\
Roots & Ethanol & 11.2 & 5.6 \\
& Water & 8.4 & 4.2 \\
\hline
\end{tabular}

activities ranging from 6.10 to $13.87 \mathrm{~mm}$, and the aqueous extracts resulted in the zones of inhibition ranging from 0.80 to $4.10 \mathrm{~mm}$.

\subsection{Minimum Inhibitory Concentration (MIC) of the Crude} Extracts. The minimum inhibitory concentration (MIC) assay was employed to evaluate the effectiveness of the extracts that showed significant antimicrobial activities in the previous tests. MIC was determined for extracts that showed diameter greater than or equal to $7 \mathrm{~mm}$ of the growth inhibition zone at $25 \mathrm{mg} / \mathrm{ml}$. All pathogens were added to the diluted ethanol extracts of concentrations ranging from $3.125 \mathrm{mg} / \mathrm{ml}$ to $12.5 \mathrm{mg} / \mathrm{ml}$. The results are shown in Table 7. The data revealed that the MIC of ethanolic extracts ranged from $3.125 \mathrm{mg} / \mathrm{ml}$ bark and root extracts for C. jejuni. Leaf ethanol extract also scores $3.125 \mathrm{mg} / \mathrm{ml}$ on L. monocytogenes. Generally, the bark ethanol extracts had the lowest MIC, and the highest was for the leaf and stem ethanol extracts.

\section{Discussion}

The results of crude extract yields clearly showed that the percentage yield of the crude extracts of different plant parts varied from solvent to solvent. This could be attributed to different polarities and extracting potential of the solvents. Ethanol might be dissolved polar and nonpolar substances. As Justine et al. [37] reported, most antimicrobial agents that have been identified from plants are soluble in organic solvents, and this reveals the better efficiency of ethanol as an extracting solvent than aqueous. Table 1 also approved that the percentage yields of the crude extracts using the same extracting solvent varied from one part of the plant to the other. So, in the current study, when different plant parts were compared for their yield, the leaf extracts gave the maximum yield and the root extract the least for both extracting solvents. This indicates that the bioactive ingredients are not found uniformly through the plant, and some plant parts tend to have more bioactive compounds [38].

The screening of secondary metabolic chemicals from parts of $C$. aurea revealed that the major secondary compound groups were found in different parts of the plant and solvent type (Table 2 ). This finding has concurred with the report of [8] alkaloids, cardiac glycosides, flavonoids, phenols, phytosteroids, saponins, terpenoids, and tannins from C. aurea parts by the ethanolic extract. The report of [39-41] indicated that alkaloid, tannin, flavonoid, and saponin were
TABLE 2: Screening of major secondary metabolites from parts of C. aurea.

\begin{tabular}{lcccccccc}
\hline & \multicolumn{3}{c}{ Ethanol extract of } & \multicolumn{4}{c}{$\begin{array}{c}\text { Aquatic extract of } \\
\text { C. aurea parts }\end{array}$} \\
& Leaf & Bark & Stem & Root & Leaf & Bark & Stem & Root \\
\hline Alkaloids & + & + & - & - & + & + & - & + \\
Tannins & + & - & + & - & + & - & - & - \\
Flavonoids & + & + & - & + & + & + & - & - \\
Terpenoids & + & - & - & + & - & - & - & - \\
Saponins & + & + & + & - & + & - & - & + \\
Steroids & - & + & & + & - & - & - & - \\
Phlobatannins & - & - & + & - & - & - & - & - \\
\hline
\end{tabular}

$(+)$ indicates the presence of suspected phytochemicals. $(-)$ indicates the absence of suspected phytochemicals.

present, but terpenoid and steroid were absent in $80 \%$ methanol extract of $C$. aurea leaves. The preliminary phytochemical analysis of $70 \%$ ethanolic extracts from the C. aurea seeds showed the presence of tannins, flavonoids, terpenoids, saponins, steroids, glycosides, and alkaloids compounds [41]. The stem and bark hexane extract of C. aurea yielded the widely studied isoflavonoids and alkaloid-type phytochemicals [42].

The phytochemical screening and qualitative estimation of $C$. aurea seeds and leaves showed that the leaves were rich in flavones and polyphenols than the seeds, yet the seeds are rich in alkaloids and tannins than the leaves of C. aurea [43]. Adedapo et al. [9] in their investigations showed that C. aurea has resulted in the isolation of a series of alkaloids, phenolic compounds, flavonoids, flavanols, and proanthocyanins from leaves, barks, and roots. The present finding was also in line with the report of Dula and Zelalem [44] which showed that the C. aurea root extract contains cardiac glycosides, tannins, flavonoids, terpenoids, saponins, steroids, alkaloids, and phenolic compounds by using ethanol, chloroform, methanol, and n-hexane extracts. Even if a standardized extraction protocol has not been developed for herbal extracts, $20-95 \%$ of the ethanol-aqueous mixture is frequently used by the herbal medicine industry to prepare ethanolic extracts [11]. Therefore, ethanol is widely used to obtain crude extracts of phytochemicals from plant materials in the herbal medicine industry for medication purposes. Due to the variation in the composition of active compounds, a given plant may require different concentrations of ethanol to achieve the maximum recovery of bioactive components. Moreover, the variation of secondary compounds may also exist within species 
TAвLE 3: Antibacterial activity of crude extracts of the leaf and antibiotics against the test pathogens (mean $\pm \mathrm{SD}, n=3)$.

\begin{tabular}{|c|c|c|c|c|c|c|c|c|}
\hline \multirow[b]{3}{*}{ Tested pathogens } & \multicolumn{8}{|c|}{ Zone of inhibition } \\
\hline & \multicolumn{3}{|c|}{ Crude extract solvents from the leaf } & \multirow[b]{2}{*}{$\begin{array}{l}\text { Conc. } \\
\text { Ml/Mg }\end{array}$} & \multicolumn{3}{|c|}{ Antibiotics } & \multirow[b]{2}{*}{$\begin{array}{c}\text { Tetracycline } \\
(\text { mean } \pm \text { SD }) \\
(\mathrm{mm})\end{array}$} \\
\hline & $\begin{array}{l}\text { Conc. } \\
\text { Ml (mg) }\end{array}$ & $\begin{array}{c}\text { Water } \\
(\text { mean } \pm S D) \\
(\mathrm{mm})\end{array}$ & $\begin{array}{c}\text { Ethanol } \\
(\mathrm{mean} \pm \mathrm{SD}) \\
(\mathrm{mm})\end{array}$ & & $\begin{array}{c}\text { Ciprofloxacin } \\
(\text { mean } \pm \text { SD }) \\
(\mathrm{mm})\end{array}$ & $\begin{array}{c}\text { Amoxicillin } \\
(\text { mean } \pm S D) \\
(\mathrm{mm})\end{array}$ & $\begin{array}{c}\text { Penicillin } \\
(\text { mean } \pm \text { SD }) \\
(\mathrm{mm})\end{array}$ & \\
\hline \multirow{2}{*}{ S. aureus } & 25 & $3.57 \pm 0.89^{\mathrm{Aa}}$ & $11.2 \pm 1.08^{\mathrm{Ab}}$ & 0.1 & $11.83 \pm 0.40^{\mathrm{Cc}}$ & $13.37 \pm 0.31^{\mathrm{Ad}}$ & - & $21.13 \pm 1.07^{\mathrm{Bf}}$ \\
\hline & 50 & $6.4 \pm 1.74^{\mathrm{Ba}}$ & $15.17 \pm 1.73^{\mathrm{Eb}}$ & 0.2 & $11.93 \pm 1.03^{\mathrm{Cc}}$ & $20.1 \pm 1.59^{\mathrm{Cd}}$ & - & $28.63 \pm 3.06^{\mathrm{Df}}$ \\
\hline \multirow[b]{2}{*}{ S. pyogenes } & 25 & $5.5 \pm 0.47^{\mathrm{Da}}$ & $17.83 \pm 1.29^{\mathrm{Fb}}$ & 0.1 & $29.13 \pm 1.97^{\mathrm{Fc}}$ & $15.7 \pm 0.76^{\mathrm{Bd}}$ & $12.6 \pm 0.58^{\mathrm{Ae}}$ & $11.47 \pm 0.66^{\mathrm{Aa}}$ \\
\hline & 50 & $6.53 \pm 0.97^{\mathrm{Ca}}$ & $13.3 \pm 1.30^{\mathrm{Ab}}$ & 0.2 & $30.47 \pm 0.88^{\mathrm{Fc}}$ & $29.97 \pm 1.71^{\mathrm{Fc}}$ & $30.13 \pm 0.83^{\mathrm{Fe}}$ & $25.47 \pm 4.35^{\mathrm{Cf}}$ \\
\hline \multirow{2}{*}{ L. monocytogenes } & 25 & $3.07 \pm 1.34^{\mathrm{Aa}}$ & $19.67 \pm 0.59^{\mathrm{Fb}}$ & 0.1 & $19.6 \pm 0.56^{\mathrm{Ac}}$ & $17.83 \pm 0.87^{\mathrm{Bd}}$ & $16.7 \pm 0.80^{\mathrm{Be}}$ & $31.33 \pm 1.61^{\mathrm{Ff}}$ \\
\hline & 50 & $5.6 \pm 1.81^{\mathrm{Da}}$ & $9.63 \pm 0.74^{\mathrm{Cb}}$ & 0.2 & $25.8 \pm 1.44^{\mathrm{Bc}}$ & $23.23 \pm 4.33^{\mathrm{Cd}}$ & $28.2 \pm 2.08^{\mathrm{Ee}}$ & $31.63 \pm 0.66^{\mathrm{Ff}}$ \\
\hline \multirow{2}{*}{ E. coli $\mathrm{O} 157 \mathrm{H}: 7$} & 25 & $4.07 \pm 0.52^{\mathrm{Aa}}$ & $11.47 \pm 0.66^{\mathrm{Bb}}$ & 0.1 & $17.3 \pm 3.62^{\mathrm{Ac}}$ & $13.03 \pm 2.61^{\mathrm{Ad}}$ & - & $25.53 \pm 3.16^{\mathrm{Cf}}$ \\
\hline & 50 & $6.9 \pm 1.68^{\mathrm{Ca}}$ & $15.67 \pm 0.74^{\mathrm{Eb}}$ & 0.2 & $19.73 \pm 0.94^{\mathrm{Ac}}$ & $16.8 \pm 0.78^{\mathrm{Bd}}$ & - & $27.87 \pm 0.53^{\mathrm{Ef}}$ \\
\hline \multirow{2}{*}{ S. typhi } & 25 & $2.67 \pm 0.96^{\mathrm{Fa}}$ & $11.5 \pm 1.96^{\mathrm{Bb}}$ & 0.1 & $16.27 \pm 1.19^{\mathrm{Dc}}$ & $26.57 \pm 2.36^{\mathrm{Ec}}$ & $15.2 \pm 0.70^{\mathrm{Be}}$ & $23.77 \pm 1.35^{\mathrm{Cf}}$ \\
\hline & 50 & $1.7 \pm 0.89^{\mathrm{Ea}}$ & $13.23 \pm 0.96^{\mathrm{Ab}}$ & 0.2 & $22.27 \pm 1.14^{\mathrm{Ec}}$ & $26.87 \pm 1.62^{\mathrm{Ec}}$ & $23.87 \pm 3.72^{\mathrm{Ce}}$ & $28.13 \pm 3.62^{\mathrm{Ef}}$ \\
\hline \multirow{2}{*}{ C. jejuni } & 25 & $3.1 \pm 0.82^{\mathrm{Aa}}$ & $10.1 \pm 0.32^{\mathrm{Cb}}$ & 0.1 & $29.03 \pm 1.26^{\mathrm{Fc}}$ & $19.97 \pm 0.77^{\mathrm{Cd}}$ & $23.1 \pm 2.0^{\mathrm{Ce}}$ & $15.67 \pm 0.90^{\mathrm{Af}}$ \\
\hline & 50 & $4.1 \pm 0.87^{\mathrm{Ba}}$ & $12.23 \pm 1.04^{\mathrm{Bb}}$ & 0.2 & $31.37 \pm 0.86^{\mathrm{Fc}}$ & $23.6 \pm 3.49^{\mathrm{Cd}}$ & $25.6 \pm 2.25^{\mathrm{De}}$ & $18.2 \pm 1.49^{\mathrm{Bf}}$ \\
\hline
\end{tabular}

$n=$ number of experimental replicates; $\mathrm{SD}=$ standard deviation; means with the same letter (lower case) in the same row are not significantly different; means with the same letter (upper case) in the same column are not significantly different.

TABLE 4: Antibacterial activity of crude extracts of the stem and antibiotics against the test pathogens (mean $\pm \mathrm{SD}, n=3)$.

\begin{tabular}{|c|c|c|c|c|c|c|c|c|}
\hline \multirow[b]{3}{*}{ Tested pathogens } & \multicolumn{8}{|c|}{ Zone of inhibition } \\
\hline & \multicolumn{3}{|c|}{ Crude extract solvents from the stem } & \multicolumn{5}{|c|}{ Antibiotics } \\
\hline & $\begin{array}{l}\text { Conc. } \\
\text { Ml (mg) }\end{array}$ & $\begin{array}{c}\text { Water } \\
(\text { mean } \pm \mathrm{SD}) \\
(\mathrm{mm})\end{array}$ & $\begin{array}{c}\text { Ethanol } \\
(\text { mean } \pm S D) \\
(\mathrm{mm})\end{array}$ & $\begin{array}{l}\text { Conc. } \\
\mathrm{Ml} / \mathrm{Mg}\end{array}$ & $\begin{array}{c}\text { Ciprofloxacin } \\
(\text { mean } \pm \text { SD }) \\
(\mathrm{mm})\end{array}$ & $\begin{array}{c}\text { Amoxicillin } \\
(\text { mean } \pm \mathrm{SD}) \\
(\mathrm{mm})\end{array}$ & $\begin{array}{c}\text { Penicillin } \\
(\text { mean } \pm \text { SD }) \\
(\mathrm{mm})\end{array}$ & $\begin{array}{c}\text { Tetracycline } \\
(\text { mean } \pm \text { SD }) \\
(\mathrm{mm})\end{array}$ \\
\hline \multirow{2}{*}{ S. aureus } & 25 & $1.67 \pm 0.50^{\mathrm{Aa}}$ & $6.33 \pm 0.76^{\mathrm{Ab}}$ & 0 . & $11.83 \pm 0.40^{\mathrm{Ac}}$ & $13.37 \pm 0.31^{\mathrm{Ad}}$ & - & $21.13 \pm 1.07^{\mathrm{Cf}}$ \\
\hline & 50 & $1.13 \pm 0.82^{\mathrm{Aa}}$ & $7.8 \pm 1.38^{\mathrm{Bb}}$ & 0.2 & $11.93 \pm 1.03^{\mathrm{Ac}}$ & $20.1 \pm 1.59^{\mathrm{Cd}}$ & - & $28.63 \pm 3.06^{\mathrm{Ef}}$ \\
\hline \multirow[b]{2}{*}{ S. pyogenes } & 25 & $2.1 \pm 1.16^{\mathrm{Ba}}$ & $10.17 \pm 2.44^{\mathrm{Cb}}$ & 0.1 & $29.13 \pm 1.97^{\mathrm{Ec}}$ & $15.7 \pm 0.76^{\mathrm{Bd}}$ & $12.6 \pm 0.58^{\mathrm{Ae}}$ & $11.47 \pm 0.66^{\mathrm{Aa}}$ \\
\hline & 50 & $5.8 \pm 0.41^{\mathrm{Fa}}$ & $15.87 \pm 1.88^{\mathrm{Db}}$ & 0 & $30.47 \pm 0.88^{\mathrm{Fc}}$ & $29.97 \pm 1.71^{\mathrm{Fd}}$ & $30.13 \pm 0.83^{\mathrm{Fe}}$ & $25.47 \pm 4.35^{\mathrm{Df}}$ \\
\hline \multirow{2}{*}{ L. monocytogenes } & 25 & $1.63 \pm 0.58^{\mathrm{Aa}}$ & $6.4 \pm 0.97^{\mathrm{Ab}}$ & 0.1 & $19.6 \pm 0.56^{\mathrm{Cc}}$ & $17.83 \pm 0.87^{\mathrm{Cd}}$ & $16.7 \pm 0.80^{\mathrm{Be}}$ & $31.33 \pm 1.61^{\mathrm{Ff}}$ \\
\hline & 50 & $7.3 \pm 0.39^{\mathrm{Fa}}$ & $14.67 \pm 0.68^{\mathrm{Db}}$ & 0.2 & $25.8 \pm 1.44^{\mathrm{Dc}}$ & $23.23 \pm 4.33^{\mathrm{Dd}}$ & $28.2 \pm 2.08^{\mathrm{Ee}}$ & $31.63 \pm 0.66^{\mathrm{Ff}}$ \\
\hline \multirow{2}{*}{ E. coli $\mathrm{O} 157 \mathrm{H}: 7$} & 25 & $3.47 \pm 0.76^{\mathrm{Ca}}$ & $12.03 \pm 1.97^{\mathrm{Cb}}$ & 0.1 & $17.3 \pm 3.62^{\mathrm{Bc}}$ & $13.03 \pm 2.61^{\mathrm{Ad}}$ & - & $25.53 \pm 3.16^{\mathrm{Df}}$ \\
\hline & 50 & $7.8 \pm 1.55^{\mathrm{Fa}}$ & $12.47 \pm 0.75^{\mathrm{Cb}}$ & 0.2 & $19.73 \pm 0.94^{\mathrm{Cc}}$ & $16.8 \pm 0.78^{\mathrm{Bd}}$ & - & $27.87 \pm 0.53^{\mathrm{Ef}}$ \\
\hline \multirow{2}{*}{ S. typhi } & 25 & $3.87 \pm 1.42^{\mathrm{Ea}}$ & $12.13 \pm 0.69^{\mathrm{Cb}}$ & 0.1 & $16.27 \pm 1.19^{\mathrm{Bc}}$ & $26.57 \pm 2.36^{\mathrm{Ed}}$ & $15.2 \pm 0.70^{\mathrm{Be}}$ & $23.77 \pm 1.35^{\mathrm{Cf}}$ \\
\hline & 50 & $3.7 \pm 0.76^{\mathrm{Ea}}$ & $16.77 \pm 1.27^{\mathrm{Eb}}$ & 0.2 & $22.27 \pm 1.14^{\mathrm{Dc}}$ & $26.87 \pm 1.62^{\mathrm{Ed}}$ & $23.87 \pm 3.72^{\mathrm{Ce}}$ & $28.13 \pm 3.62^{\mathrm{Ef}}$ \\
\hline \multirow{2}{*}{ C. jejuni } & 25 & $1.47 \pm 0.68^{\mathrm{Aa}}$ & $11.5 \pm 1.05^{\mathrm{Cb}}$ & 0.1 & $29.03 \pm 1.26^{\mathrm{Ec}}$ & $19.97 \pm 0.77^{\mathrm{Cd}}$ & $23.1 \pm 2.0^{\mathrm{Ce}}$ & $15.67 \pm 0.90^{\mathrm{Ba}}$ \\
\hline & 50 & $2.43 \pm 0.75^{\mathrm{Ba}}$ & $12.2 \pm 2.19^{\mathrm{Cb}}$ & 0.2 & $31.37 \pm 0.86^{\mathrm{Fc}}$ & $23.6 \pm 3.49^{\mathrm{Dd}}$ & $25.6 \pm 2.25^{\mathrm{De}}$ & $18.2 \pm 1.49^{\mathrm{Bf}}$ \\
\hline
\end{tabular}

$n=$ number of experimental replicates; $\mathrm{SD}=$ standard deviation; means with the same letter (lower case) in the same row are not significantly different; means with the same letter (upper case) in the same column are not significantly different.

and breed mainly due to plant genotypes, developmental stages, biotic factors (natural enemies, competitors, or mutualists), soil type and ingredients, the season of collection, and geographical locations $[12,45]$.

The present study indicated that the antibacterial activity of the ethanol extracts of $C$. aurea is much higher than aquatic extracts comparable to that of standard antibiotics. According to Adedapo et al. [9], stem extract by methanol had antibacterial activities, but in the current study, leaf extracts by ethanol had high antibacterial activities; the difference in the finding might be due to types of extracts.

Kulthe et al. and Tahera et al. [46, 47] reported the antibacterial activity of Calpurnia leaf extracts against nine enteric pathogens tested including E. coli O157 H:7, S. typhi, and other species. Likewise, Romha et al. and Kalayou et al.
$[48,49]$ reported the antibacterial activity of Calpurnia leaf extracts against E. coli, S. typhi, S. pyogenes, and S. aureus clinical isolates. C. jejuni shows MIC on the leaf, bark, and root, while $L$. monocytogenes shows on leaf $(3.125 \mathrm{mg} / \mathrm{ml})$ ethanol extracts of $C$. aurea which is in line with the finding of Elisha et al. [14]. As commonly known, the Gram-negative bacteria are more resistant than the Gram-positive ones [9]; however, the current study showed that 3 of the Gram-negative bacteria used in this study were sensitive to this extract even at a high MIC of $3.125 \mathrm{mg} / \mathrm{ml}$. Among the positive controls, antibiotic treatment with penicillin showed resistance to E. coli $\mathrm{O} 157 \mathrm{H}: 7$ and S. aureus at 0.1 and $0.2 \mathrm{mg} / \mathrm{ml}$. This suggests that the C. aurea ethanol extract compound might be used instead of penicillin treatment of these disease-causing pathogens. 
TABle 5: Antibacterial activity of crude extracts of the bark and antibiotics against the test pathogens (mean \pm SD, $n=3$ ).

\begin{tabular}{|c|c|c|c|c|c|c|c|c|}
\hline \multirow[b]{3}{*}{ Tested pathogens } & \multicolumn{8}{|c|}{ Zone of inhibition } \\
\hline & \multicolumn{3}{|c|}{ Crude extract solvents from the bark } & \multicolumn{5}{|c|}{ Antibiotics } \\
\hline & $\begin{array}{l}\text { Conc. } \\
\text { Ml (mg) }\end{array}$ & $\begin{array}{c}\text { Water } \\
(\text { mean } \pm S D) \\
(\mathrm{mm})\end{array}$ & $\begin{array}{c}\text { Ethanol } \\
(\text { mean } \pm S D) \\
(\mathrm{mm})\end{array}$ & $\begin{array}{l}\text { Conc. } \\
\mathrm{Ml} / \mathrm{Mg}\end{array}$ & $\begin{array}{c}\text { Ciprofloxacin } \\
(\text { mean } \pm \text { SD }) \\
(\mathrm{mm})\end{array}$ & $\begin{array}{c}\text { Amoxicillin } \\
(\text { mean } \pm \mathrm{SD}) \\
(\mathrm{mm})\end{array}$ & $\begin{array}{c}\text { Penicillin } \\
(\text { mean } \pm \text { SD }) \\
(\mathrm{mm})\end{array}$ & $\begin{array}{c}\text { Tetracycline } \\
(\text { mean } \pm S D) \\
(\mathrm{mm})\end{array}$ \\
\hline \multirow{2}{*}{ S. aureus } & 25 & $1.67 \pm 0.52^{\mathrm{Aa}}$ & $10.6 \pm 0.93^{\mathrm{Bb}}$ & 0.1 & $11.83 \pm 0.40^{\mathrm{Fb}}$ & $13.37 \pm 0.31^{\mathrm{Fb}}$ & - & $21.13 \pm 1.07^{\mathrm{Cf}}$ \\
\hline & 50 & $2.3 \pm 0.18^{\mathrm{Ba}}$ & $10.83 \pm 2.07^{\mathrm{Bb}}$ & 0.2 & $11.93 \pm 1.03^{\mathrm{Fb}}$ & $20.1 \pm 1.59^{\mathrm{Dd}}$ & - & $28.63 \pm 3.06^{\mathrm{Ef}}$ \\
\hline \multirow[b]{2}{*}{ S. pyogenes } & 25 & $0.97 \pm 0.18^{\mathrm{Ag}}$ & $10.2 \pm 0.76^{\mathrm{Bb}}$ & 0.1 & $29.13 \pm 1.97^{\mathrm{Bc}}$ & $15.7 \pm 0.76^{\mathrm{Ed}}$ & $12.6 \pm 0.58^{\mathrm{Aa}}$ & $11.47 \pm 0.66^{\mathrm{Ab}}$ \\
\hline & 50 & $3.1 \pm 0.24^{\mathrm{Ca}}$ & $13.5 \pm 0.99^{\mathrm{Eb}}$ & 0.2 & $30.47 \pm 0.88^{\mathrm{Ac}}$ & $29.97 \pm 1.71^{\mathrm{Ad}}$ & $30.13 \pm 0.83^{\mathrm{Fe}}$ & $25.47 \pm 4.35^{\mathrm{Df}}$ \\
\hline \multirow{2}{*}{ L. monocytogenes } & 25 & $1.77 \pm 0.22^{\mathrm{Aa}}$ & $8.07 \pm 0.49^{\mathrm{Aa}}$ & 0.1 & $19.6 \pm 0.56^{\mathrm{Dc}}$ & $17.83 \pm 0.87^{\mathrm{Fd}}$ & $16.7 \pm 0.80^{\mathrm{Bc}}$ & $31.33 \pm 1.61^{\mathrm{Ff}}$ \\
\hline & 50 & $2.57 \pm 0.21^{\mathrm{Ba}}$ & $9.97 \pm 1.04^{\mathrm{Ab}}$ & 0.2 & $25.8 \pm 1.44^{\mathrm{Cc}}$ & $23.23 \pm 4.33^{\mathrm{Cd}}$ & $28.2 \pm 2.08^{\mathrm{Ee}}$ & $31.63 \pm 0.66^{\mathrm{Ff}}$ \\
\hline \multirow{2}{*}{ E. coli $\mathrm{O} 157 \mathrm{H}: 7$} & 25 & $1.03 \pm 0.18^{\mathrm{Aa}}$ & $10.33 \pm 0.94^{\mathrm{Bb}}$ & 0.1 & $17.3 \pm 3.62^{\mathrm{Ec}}$ & $13.03 \pm 2.61^{\mathrm{Fd}}$ & - & $25.53 \pm 3.16^{\mathrm{Df}}$ \\
\hline & 50 & $5.23 \pm 0.77^{\mathrm{Ea}}$ & $13.23 \pm 3.24^{\mathrm{Eb}}$ & 0.2 & $19.73 \pm 0.94^{\mathrm{Dc}}$ & $16.8 \pm 0.78^{\mathrm{Ed}}$ & - & $27.87 \pm 0.53^{\mathrm{Ef}}$ \\
\hline \multirow{2}{*}{ S. typhi } & 25 & $2.13 \pm 0.60^{\mathrm{Ba}}$ & $11.13 \pm 1.97^{\mathrm{Cb}}$ & 0.1 & $16.27 \pm 1.19^{\mathrm{Ec}}$ & $26.57 \pm 2.36^{\mathrm{Bd}}$ & $15.2 \pm 0.70^{\mathrm{Bc}}$ & $23.77 \pm 1.35^{\mathrm{Cf}}$ \\
\hline & 50 & $4.2 \pm 1.71^{\mathrm{Da}}$ & $12.77 \pm 3.63^{\mathrm{Db}}$ & 0.2 & $22.27 \pm 1.14^{\mathrm{Cc}}$ & $26.87 \pm 1.62^{\mathrm{Bd}}$ & $23.87 \pm 3.72^{\mathrm{Cc}}$ & $28.13 \pm 3.62^{\mathrm{Ef}}$ \\
\hline \multirow[b]{2}{*}{ C. jejuni } & 25 & $1.1 \pm 0.27^{\mathrm{Aa}}$ & $12.5 \pm 0.50^{\mathrm{Db}}$ & 0.1 & $29.03 \pm 1.26^{\mathrm{Bc}}$ & $19.97 \pm 0.77^{\mathrm{Dd}}$ & $23.1 \pm 2.0^{\mathrm{Cc}}$ & $15.67 \pm 0.90^{\mathrm{Bb}}$ \\
\hline & 50 & $2.63 \pm 0.85^{\mathrm{Ba}}$ & $12.47 \pm 1.43^{\mathrm{Db}}$ & 0.2 & $31.37 \pm 0.86^{\mathrm{Ac}}$ & $23.6 \pm 3.49^{\mathrm{Cd}}$ & $25.6 \pm 2.25^{\mathrm{De}}$ & $18.2 \pm 1.49^{\mathrm{Bf}}$ \\
\hline
\end{tabular}

$n=$ number of experimental replicates; $\mathrm{SD}=$ standard deviation; means with the same letter (lower case) in the same row are not significantly different; means with the same letter (upper case) in the same column are not significantly different.

TABle 6: Antibacterial activity of crude extracts of the root and antibiotics against the test pathogens (mean $\pm \mathrm{SD}, n=3$ ).

\begin{tabular}{|c|c|c|c|c|c|c|c|c|}
\hline \multirow[b]{3}{*}{ Tested pathogens } & \multicolumn{8}{|c|}{ Zone of inhibition } \\
\hline & \multicolumn{3}{|c|}{ Crude extract solvents from the root } & \multicolumn{5}{|c|}{ Antibiotics } \\
\hline & $\begin{array}{l}\text { Conc. } \\
\text { Ml (mg) }\end{array}$ & $\begin{array}{c}\text { Water } \\
(\text { mean } \pm \mathrm{SD}) \\
(\mathrm{mm})\end{array}$ & $\begin{array}{c}\text { Ethanol } \\
(\text { mean } \pm \text { SD }) \\
(\mathrm{mm})\end{array}$ & $\begin{array}{l}\text { Conc. } \\
\mathrm{Ml} / \mathrm{Mg}\end{array}$ & $\begin{array}{c}\text { Ciprofloxacin } \\
(\text { mean } \pm \text { SD }) \\
(\mathrm{mm})\end{array}$ & $\begin{array}{c}\text { Amoxicillin } \\
(\text { mean } \pm \text { SD }) \\
(\mathrm{mm})\end{array}$ & $\begin{array}{c}\text { Penicillin } \\
(\mathrm{mean} \pm \mathrm{SD}) \\
(\mathrm{mm})\end{array}$ & $\begin{array}{c}\text { Tetracycline } \\
(\mathrm{mean} \pm \mathrm{SD}) \\
(\mathrm{mm})\end{array}$ \\
\hline \multirow{2}{*}{ S. aureus } & 25 & $1.23 \pm 0.40^{\mathrm{Aa}}$ & $6.37 \pm 0.50^{\mathrm{Aa}}$ & 0.1 & $11.83 \pm 0.40^{\mathrm{Ab}}$ & $13.37 \pm 0.31^{\mathrm{Ab}}$ & - & $21.13 \pm 1.07^{\mathrm{Cf}}$ \\
\hline & 50 & $3.9 \pm 1.32^{\mathrm{Da}}$ & $7.7 \pm 0.50^{\mathrm{Bb}}$ & 0.2 & $11.93 \pm 1.03^{\mathrm{Ab}}$ & $20.1 \pm 1.59^{\mathrm{Cd}}$ & - & $28.63 \pm 3.06^{\mathrm{Ef}}$ \\
\hline \multirow{2}{*}{ S. pyogenes } & 25 & $3.87 \pm 0.83^{\mathrm{Da}}$ & $9.37 \pm 0.74^{\mathrm{Cb}}$ & 0.1 & $29.13 \pm 1.97^{\mathrm{Ec}}$ & $15.7 \pm 0.76^{\mathrm{Bd}}$ & $12.6 \pm 0.58^{\mathrm{Ab}}$ & $11.47 \pm 0.66^{\mathrm{Ab}}$ \\
\hline & 50 & $4.1 \pm 0.18^{\mathrm{Ea}}$ & $11.73 \pm 1.39^{\mathrm{Db}}$ & 0.2 & $30.47 \pm 0.88^{\mathrm{Fc}}$ & $29.97 \pm 1.71^{\mathrm{Fd}}$ & $30.13 \pm 0.83^{\mathrm{Fe}}$ & $25.47 \pm 4.35^{\mathrm{Df}}$ \\
\hline \multirow{2}{*}{ L. monocytogenes } & 25 & $1.67 \pm 0.44^{\mathrm{Aa}}$ & $6.1 \pm 0.47^{\mathrm{Aa}}$ & 0.1 & $19.6 \pm 0.56^{\mathrm{Cc}}$ & $17.83 \pm 0.87^{\mathrm{Bd}}$ & $16.7 \pm 0.80^{\mathrm{Cd}}$ & $31.33 \pm 1.61^{\mathrm{Ff}}$ \\
\hline & 50 & $1.7 \pm 0.36^{\mathrm{Aa}}$ & $9.5 \pm 0.56^{\mathrm{Cb}}$ & 0.2 & $25.8 \pm 1.44^{\mathrm{Dc}}$ & $23.23 \pm 4.33^{\mathrm{Dd}}$ & $28.2 \pm 2.08^{\mathrm{Ee}}$ & $31.63 \pm 0.66^{\mathrm{Ff}}$ \\
\hline \multirow{2}{*}{ E. coli $\mathrm{O} 157 \mathrm{H}: 7$} & 25 & $3.47 \pm 0.49^{\mathrm{Da}}$ & $11.87 \pm 1.19^{\mathrm{Db}}$ & 0.1 & $17.3 \pm 3.62^{\mathrm{Bc}}$ & $13.03 \pm 2.61^{\mathrm{Ab}}$ & - & $25.53 \pm 3.16^{\mathrm{Df}}$ \\
\hline & 50 & $3.43 \pm 0.49^{\mathrm{Da}}$ & $13.87 \pm 1.09^{\mathrm{Fb}}$ & 0.2 & $19.73 \pm 0.94^{\mathrm{Cc}}$ & $16.8 \pm 0.78^{\mathrm{Bd}}$ & - & $27.87 \pm 0.53^{\mathrm{Ef}}$ \\
\hline \multirow{2}{*}{ S. typhi } & 25 & $0.8 \pm 0.09^{\mathrm{Bg}}$ & $9.53 \pm 0.50^{\mathrm{Cb}}$ & 0.1 & $16.27 \pm 1.19^{\mathrm{Bc}}$ & $26.57 \pm 2.36^{\mathrm{Ed}}$ & $15.2 \pm 0.70^{\mathrm{Cd}}$ & $23.77 \pm 1.35^{\mathrm{Cf}}$ \\
\hline & 50 & $1.57 \pm 0.36^{\mathrm{Aa}}$ & $12.57 \pm 1.18^{\mathrm{Eb}}$ & 0.2 & $22.27 \pm 1.14^{\mathrm{Dc}}$ & $26.87 \pm 1.62^{\mathrm{Ed}}$ & $23.87 \pm 3.72^{\mathrm{Dc}}$ & $28.13 \pm 3.62^{\mathrm{Ef}}$ \\
\hline \multirow{2}{*}{ C. jejuni } & 25 & $1.27 \pm 0.3^{\mathrm{Aa}}$ & $11.13 \pm 1.08^{\mathrm{Db}}$ & 0.1 & $29.03 \pm 1.26^{\mathrm{Ec}}$ & $19.97 \pm 0.77^{\mathrm{Cd}}$ & $23.1 \pm 2.0^{\mathrm{De}}$ & $15.67 \pm 0.90^{\mathrm{Bf}}$ \\
\hline & 50 & $2.63 \pm 0.28^{\mathrm{Ca}}$ & $9.37 \pm 0.57^{\mathrm{Cb}}$ & 0.2 & $31.37 \pm 0.86^{\mathrm{Fc}}$ & $23.6 \pm 3.49^{\mathrm{Dd}}$ & $25.6 \pm 2.25^{\mathrm{Ee}}$ & $18.2 \pm 1.49^{\mathrm{Bf}}$ \\
\hline
\end{tabular}

$n=$ number of experimental replicates; $\mathrm{SD}=$ standard deviation; means with the same letter (lower case) in the same row are not significantly different; means with the same letter (upper case) in the same column are not significantly different.

TABLe 7: Minimum inhibitory concentration (MIC) of the extracts of leaves, fruits, stems, and roots of C. aurea against bacterial test pathogens in $\mathrm{mg} / \mathrm{ml}$.

\begin{tabular}{|c|c|c|c|c|}
\hline \multicolumn{5}{|c|}{ The MIC of the ethanolic extracts $(\mathrm{mg} / \mathrm{ml})$} \\
\hline Pathogen (strain) & Leaf ethanol & Bark ethanol & Stem ethanol & Root ethanol \\
\hline S. aureus & 12.5 & 6.25 & 12.5 & 12.5 \\
\hline S. pyogenes & 6.25 & 6.25 & 12.5 & 6.25 \\
\hline L. monocytogenes & 3.125 & 6.25 & 12.5 & 12.5 \\
\hline E. coli $\mathrm{O} 157 \mathrm{H}: 7$ & 12.5 & 6.25 & 6.25 & 6.25 \\
\hline S. typhi & 12.5 & 6.25 & 6.25 & 6.25 \\
\hline C. jejuni & 3.125 & 3.125 & 6.25 & 3.125 \\
\hline
\end{tabular}




\section{Conclusion}

The current study revealed that Calpurnia aurea had alkaloids, saponins, tannins, flavonoids, terpenoids, steroids, and phlorotannins phytochemicals by aquatic and ethanol extraction methods from the plant parts (leaf, bark, stem, and root). Ethanol extract had antimicrobial activities against selected animal pathogens such as E. coli O157 H:7, S. aureus, S. typhi, S. pyogenes, S. aureus, L. monocytogenes, and C. jejuni. Also, this study showed that E. coli O157 H:7 and $S$. aureus had resistance against penicillin.

\section{Data Availability}

All the data used to support the findings of this study are available from the author upon reasonable request.

\section{Disclosure}

The funder had no role in study design, data collection, management, and analysis, decision to publish, or preparation of the manuscript.

\section{Conflicts of Interest}

The author declares that there are no conflicts of interest.

\section{Acknowledgments}

The author deeply acknowledges Ambo University for various occasions during the duration of the study. This work was financed by Ambo University.

\section{References}

[1] H. Yadav, "Medicinal plants in folk medicine system of Ethiopia," Journal Poisonous Medicinal Plant Reserve.vol. 1, no. 1, pp. 1-5, 2013.

[2] H. Tadeg, E. Mohammed, K. Asres, and T. Gebre-Mariam, "Antimicrobial activities of some selected traditional Ethiopian medicinal plants used in the treatment of skin disorders," Journal of Ethnopharmacology, vol. 100, no. 1-2, pp. 168-175, 2005.

[3] H. Agisho, M. Osie, and T. Lambore, "Traditional medicinal plants utilization, management and threats in Hadiya Zone, Ethiopia," Journal of Medicinal Plant, vol. 2, no. 2, pp. 94-108, 2014.

[4] S. Banerjee, H. Bekele, and M. B. Ahmed, "Ethno veterinary practices prevalent among livestock rearers at arbe gona and loka abaya woredas of sidama zone of southern Ethiopia," in Proceedings of the Zoological Society, vol. 68, no. 2, April 2015.

[5] L. Tiwari and P. Pande, "Ethnoveterinary medicines in Indian perspective: reference to Uttarakhand, Himalaya," 2010.

[6] G. R. Eshetu, T. A. Dejene, L. B. Telila, and D. F. Bekele, "Ethnoveterinary medicinal plants: preparation and application methods by traditional healers in selected districts of southern Ethiopia," Veterinary World, vol. 8, no. 5, pp. 674-684, 2015.

[7] M. Amante, In Vitro Louscidal and Acaricidal Activities of Alkaloid of Calpurnia Aurea and Fractions of Ricinus Communis Extracts Against Linognathus Ovillus and Amblyomma
Variegatum, Addis Ababa University, Addis Ababa, Ethiopia, 2016.

[8] M. Eyasu, W. Shibeshi, and M. Giday, "In vivo antimalarial activity of hydromethanolic leaf extract of Calpurnia aurea (Fabaceae) in Mice infected with chloroquine sensitive Plasmodium berghei," International Journal of Pharmacology, vol. 2, pp. 131-142, 2013.

[9] A. A. Adedapo, F. O. Jimoh, S. Koduru, A. J. Afolayan, and P. J. Masika, "Antibacterial and antioxidant properties of the methanol extracts of the leaves and stems of Calpurnia aurea," BMC Complementary and Alternative Medicine, vol. 8, no. 1, p. 53,2008 .

[10] G. Wondimu, "Phytochemical analysis and antibacterial activities of organic solvent extracts of Calpurnia aurea seed, root bark and root," 2019.

[11] L. Ganora, Herbal Constituent, pp. 7-168, Foundations of Phytochemistry, Davis, CA, USA, 2009.

[12] B. D. Moore, R. L. Andrew, C. Külheim, and W. J. Foley, "Explaining intraspecific diversity in plant secondary metabolites in an ecological context," New Phytologist, vol. 201, no. 3, pp. 733-750, 2014.

[13] M. Birhan, T. Tessema, A. Kenubih, and M. Yayeh, "In vitro antimicrobial evaluation of aqueus methanol extract from Calpurina aurea (Fabaceae) leaves," Asian Journal of Medicinal Pharmaceutical Research, vol. 8, no. 4, pp. 33-43, 2018.

[14] I. L. Elisha, F. S. Botha, L. J. McGaw, and J. N. Eloff, "The antibacterial activity of extracts of nine plant species with good activity against Escherichia coli against five other bacteria and cytotoxicity of extracts," BMC Complementary and Alternative Medicine, vol. 17, no. 1, p. 133, 2017.

[15] A. Gemechu, M. Giday, A. Worku, and G. Ameni, "In vitro anti-mycobacterial activity of selected medicinal plants against Mycobacterium tuberculosis and Mycobacterium bovis strains," BMC Complementary and Alternative Medicine, vol. 13, no. 1, p. 291, 2013.

[16] S. Nagalakshmi, P. Saranraj, and P. Sivasakthivelan, "Determination of minimum inhibitory concentration (MIC) and percentage bacterial growth inhibition of essential oils against gram positive bacterial pathogens," Journal of Drug Delivery and Therapeutics, vol. 9, no. 3, pp. 33-35, 2019.

[17] R. T. Barnard, "The zone of inhibition," Clinical Chemistry, vol. 65, no. 6, p. 819, 2019.

[18] K. C. Mellor, L. Petrovska, N. R. Thomson, K. Harris, S. W. Reid, and A. E. Mather, "Antimicrobial resistance diversity suggestive of distinct Salmonella Typhimurium sources or selective pressures in food-production animals," Frontiers in Microbiology, vol. 10, p. 708, 2019.

[19] A. K. Bhunia, Foodborne Microbial Pathogens: Mechanisms and Pathogenesis, Springer, Berlin, Germany, 2018.

[20] K. M. Thomas, W. A. de Glanville, G. C. Barker et al., "Prevalence of Campylobacter and Salmonella in African food animals and meat: a systematic review and meta-analysis," International Journal of Food Microbiology, vol. 2019, Article ID 108382, 2019.

[21] A. J. Kayode, E. O. Igbinosa, and A. I. Okoh, "Overview of listeriosis in the southern african hemisphere," Journal of Food Safety, Article ID e12732, 2019.

[22] A. K. Bhunia, "Introduction to foodborne pathogens," in Foodborne Microbial Pathogens, pp. 1-23, Springer, Berlin, Germany, 2018.

[23] T. S. Frana and S. J. Hau, Staphylococcosis, Diseases of Swine, pp. 926-933, John Wiley \& Sons, Inc., Hoboken, NJ, USA, 2019. 
[24] A. F. Haag, J. R. Fitzgerald, and J. R. Penadés, Staphylococcus aureus in Animals, Gram-Positive Pathogens, John Wiley \& Sons, Inc., Hoboken, NJ, USA, 2019.

[25] C. E. Turner, L. Bubba, and A. Efstratiou, Pathogenicity Factors in Group C and G Streptococci," Gram-Positive Pathogens, John Wiley \& Sons, Inc., Hoboken, NJ, USA, 2019.

[26] Central Statistical Authority, Livestock and Fishery Bureau of West Shewa Zone Toke Kutaye District, Guder, Central Statistical Authority, New Delhi, India, 2019.

[27] C. Nduagu, E. Ekefan, and A. Nwankiti, "Effect of some crude plant extracts on growth of Colletotrichum capsici (Synd) Butler \& Bisby, causal agent of pepper anthracnose," Journal of Applied Biosciences, vol. 6, no. 2, pp. 184-190, 2008.

[28] S. Dewanjee, M. Kundu, A. Maiti, R. Majumdar, A. Majumdar, and S. Mandel, "In vitro evaluation of antimicrobial activity of crude extract from plants Diospyros peregrina, Coccinia grandis and Swietenia macrophylla," Tropical Journal of Pharmaceutical Research, vol. 6, no. 3, pp. 773-778, 2007.

[29] M. Arora, R. Arora, S. Mourya et al., "Development of petrolalcohol-water microemulsion Fuel as a substitute for petrol and ethanol-blended petrol," in Proceedings of the 2008 Spring National Meeting, New Orleans, LA, USA, April 2008.

[30] W. Braide, I. Odiong, and S. Oranusi, "Phytochemical and antibacterial properties of the seed of watermelon (Citrullus lanatus)," Prime Journal of Microbiology Research (PJMR), vol. 2, no. 3, pp. 99-104, 2012.

[31] S. Shaik, H. Chen, and D. Janardanan, "Exchange-enhanced reactivity in bond activation by metal-oxo enzymes and synthetic reagents," Nature Chemistry, vol. 3, no. 1, p. 19, 2011.

[32] V. Gayathri and D. Kiruba, "Preliminary phytochemical analysis of leaf powder extracts of Psidium guajava L," International Journal of Pharmacognosy and Phytochemical Research, vol. 6, no. 2, pp. 332-334, 2014.

[33] B. Biswas, K. Rogers, F. McLaughlin, D. Daniels, and A. Yadav, "Antimicrobial activities of leaf extracts of guava (Psidium guajava L.) on two gram-negative and gram-positive bacteria," International Journal of Microbiology, vol. 2013, Article ID 746165, 2013.

[34] I. Adachukwu, O. Ann, and E. Faith, "Phytochemical analysis of paw-paw (Carica papaya) leaves," International Journal of Life Science and Biotechnology in Pharmaceutical Research, vol. 2, pp. 347-351, 2013.

[35] O. Alabi, J. Ngambi, D. Norris, and M. Mabelebele, "Effect of egg weight on hatchability and subsequent performance of Potchefstroom Koekoek chicks," Asian Journal of Animal and Veterinary Advances, vol. 7, no. 8, pp. 718-725, 2012.

[36] K. Daniels, T. Thiagarajan, and A. Aguilar, "In vitro antibacterial activity and phytochemical analysis of ethanolic leaf extracts of Cnidoscolus aconitifolius and Commelina diffusa," Biology Theses Repository, vol. 1, no. 1, 2019.

[37] V. T. Justine, M. Mustafa, S. S. Kankara, and R. Go, "Effect of drying methods and extraction solvents on phenolic antioxidants and antioxidant activity of scurrula ferruginea (jack) danser (loranthaceae) leaf extracts," Sains Malaysiana, vol. 48, no. 7, pp. 1383-1393, 2019.

[38] S. G. Wynn and B. Fougere, Veterinary Herbal Medicine, Elsevier Health Sciences, Amsterdam, Netherlands, 2006.

[39] S. Umer, A. Tekewe, and N. Kebede, "Antidiarrhoeal and antimicrobial activity of Calpurnia aurea leaf extract," BMC Complementary and Alternative Medicine, vol. 13, no. 1, p. 21, 2013.

[40] Y. M. Belayneh, E. M. Birru, and D. Ambikar, "Evaluation of hypoglycemic, antihyperglycemic and antihyperlipidemic activities of $80 \%$ methanolic seed extract of Calpurnia aurea (Ait.) Benth.(Fabaceae) in mice," Journal of Experimental Pharmacology, vol. 11, p. 73, 2019.

[41] H. Mulata, N. Gnanasekaran, U. Melaku, and S. Daniel, "Phytochemical screening and assessment of in vitro antioxidant activities of Calpurnia aurea seeds and leaves," IJPPR Human, vol. 2, no. 2, pp. 1-12, 2015.

[42] WHO, Traditional Medicine Strategy, pp. 2-5, WHO, Geneva, Switzerland, 2012.

[43] W. Mengistu, S. Daniel, and N. Gnanasekaran, "Antilipidemic properties of Calpurnia aurea leaf extract on high-fat diet induced hyperlipidemia," Pharmacognosy Research, vol. 11, no. 4, p. 389, 2019.

[44] D. Dula and A. Zelalem, "Antioxidant activity assessment of Calpurnia aurea root extract," Natural Products Chemistry and Research, vol. 6, no. 307, p. 2, 2018.

[45] C. Wendakoon, P. Calderon, and D. Gagnon, "Evaluation of selected medicinal plants extracted in different ethanol concentrations for antibacterial activity against human pathogens," Journal of Medicinally Active Plants, vol. 1, no. 2, pp. 60-68, 2012.

[46] A. A. Kulthe, V. D. Pawar, P. M. Kotecha, U. D. Chavan, and V. V. Bansode, "Development of high protein and low calorie cookies," Journal of Food Science and Technology, vol. 51, no. 1, pp. 153-157, 2014.

[47] J. Tahera, F. Feroz, J. Das Senjuti, K. Kanta Das, and R. Noor, "Demonstration of anti-bacterial activity of commonly available fruit extracts in Dhaka, Bangladesh," American Journal of Microbiological Research, vol. 2, no. 2, pp. 68-73, 2014.

[48] G. Romha, B. Admasu, T. Hiwot Gebrekidan, H. Aleme, and G. Gebru, "Antibacterial activities of five medicinal plants in Ethiopia against some human and animal pathogens," Evidence-Based Complementary and Alternative Medicine, vol. 2018, Article ID 2950758, 2018.

[49] S. Kalayou, M. Haileselassie, G. Gebre-egziabher et al., "In-vitro antimicrobial activity screening of some ethnoveterinary medicinal plants traditionally used against mastitis, wound and gastrointestinal tract complication in Tigray Region, Ethiopia," Asian Pacific Journal of Tropical Biomedicine, vol. 2, no. 7, pp. 516-522, 2012. 